\title{
Non-Modern Africa and Modern Non-Africa: Intertextual Discourse about Who We Are and Where We Came From
}

\author{
Mat J. Levitt
}

The idiom no man is an island might be rewritten as no text is an island, meaning that no text exists in literary isolation and that every piece of writing instead belongs to a landscape of others. References, endnotes, footnotes, bibliographies, and the use of phrase, term, or definition will situate a text within a discursive network of understandings, theories, paradigms, and genres. Intertextual discourses about the origins of humanity often cross generic boundaries between religion, science, informative media and entertaining fiction through the sharing and borrowing of words and concepts. These genres, however reluctantly, inevitably engage with one another in what emerges as a single discourse about who we are and where we came from. Throughout this discourse, certain concepts have formed as time, place, and identity are linguistically associated with one another. The dichotomy of Non-Modern Africa as Other and Modern Non-Africa as Self is one such concept. Caution must be exercised by researchers who wish to talk about human origins, as these types of concepts may have very real implications in political, economic, social, and cultural arenas.

InTERTEXTUALity, Discourse, AND The Significance of Naming Names

$\mathrm{T}$ The idiom "no man is an island" might be rewritten as "no text is an island," meaning that no text exists in literary isolation and that every piece of writing instead belongs to a landscape of others. References, endnotes, footnotes, bibliographies, and the use of phrase, term, or definition will situate a piece of writing within a network of understandings, theories, paradigms, and genres. Not only that, popular media forms part of the picture, too. A text can (and in many cases, will) participate in a discourse-an ongoing conversation-involving television, radio, cinema, the internet, etc. Thus, genres can be crossed, intentionally or unintentionally, through the use of a name, a phrase, an idea, or essentially any word that can be found anywhere else. A scientific journal article and a political debate can become reluctant kin through the use of common language. An audience can be transported from fiction to non-fiction by the use of a single term, like Mars Rover or Louis Pasteur. Briggs and Bauman (1992) call these referential relationships-whether implicit or explicit-intertextuality. The term describes texts that reference other texts; that is, "discourses that represent other discourses," (Briggs 1996,449). The authors explain that intertextual relations "are closely linked to social, cultural, ideological, and political-economic factors" (Briggs and Bauman 1992, 132). Let me give you an example.

In 2004, Brown et al. (2004) announced the discovery of some skeletal remains on the Indonesian island of Flores and a possible new addition to the Homo genus. Although they assigned it as Homo floresiensis, it wasn't long before people were calling the small hominin a "hobbit." Referencing the Lord of the Rings novels by J.R.R. Tolkien, as well as the recent movie trilogy based on them, as Gregory Forth explains, this term was no doubt used "in order to communicate effectively with a wider public" (Forth 2005, 16). As Forth points out, though, "curiouser still, the designation was not a creation of the popular press, but of the scientific discoverers themselves" (Forth 2005, 16). Forth describes the implications and consequences of establishing an intetextual relationship between Homo floresiensis and Tolkien's hobbits:

Casting Homo floresiensis as 'hobbits' potentially obscures the essential difference between an empirical species, designated a member of the genus 
Homo like ourselves, and the images of literary fiction. Like hobbits, both Homo floresiensis and ebu gogo are products of human imagination, but the images have different bases: tangible, skeletal and archaeological evidence in one case, and the testimony and traditions of local people in the other. Rather than simply assuming that these traditions are as fantastical as Tolkien's fiction, the challenge for social anthropologists is to discover the correct relationship between the palaeontological and ethnographic images and the true source of their resemblance [Forth 2005, 16].

Now, certainly the hobbit-izers didn't intend on all that, but therein lies the point: our words have consequences. The language we use has real significance. As researchers, the terminology we dish out about what we study affects not only ourselves, our work, and our community, but what we study and those who-whether they mean to or notbecome associated with what we say and how we say it. So, unlike Flores, no text is an island, but, like Flores, every text has the potential of being mixed up in the grand drama of humanity.

Let me give you another example. Goebel et al. $(2008,1497)$, for instance, use the term "homeland" when referring to Asia in relationship to those populations who migrated to the Americas across Berengia from Siberia. Goebel et al. use the term to establish a near instantaneous understanding amongst their readers. We all know that a "homeland" is where we come from, so referring to Asia as a homeland for early Americans utilizes this common knowledge with a single word. But the use of such terms can be problematic. The word "homeland" conjures much more than a simple definition of geographic origin; it harkens to ideas relating to identity, destiny, and belonging. Did the "first Americans" think of Asia as "home"? Would modern Native American populations appreciate the assertion that Asia is the homeland of their ancient ancestors and that they are, perhaps by semantic default, Asian? This may not have been what the authors meant to imply, but by using the term, they place themselves against a background of highly contentious subject matter.

A linguistic convention that perhaps best illustrates the process of intertextuality is the term "Out of Africa." The theory, which refers to the modern human dispersal from the African continent into Eurasia, comes with its own literary lineage. The common usage of the phrase in archaeological contexts refers primarily to the 1985 film Out of Africa starring Meryl Streep and Robert Redford. The film was based on Karen von Blixen's colonial memoir recalling her experiences in Kenya, published in 1937 under the pen name Isak Dinsesen. But the phrase wasn't invented by Blixen. In fact, it was used as the title of a 1934 travelogue by a writer known only as "H.W.," Something New Out of Africa (Feinberg and Solodow 2002, 255). And it goes back even further. In 1924, a retired civil servant from Cape Colony in South Africa-one Edward A. Judge-wrote to Senator W.E.M. Stanford: "Cotton, in fact, as a friend wrote to me the other day, is going to be another surprise from South Africa. ' $E x$ Africa semper aliquid novum', as the old Romans used to say." Essentially, the Latin phrase he used translates as "There is always something new out of Africa" (Feinberg and Solodow 2002, 256). But to what "old Romans" was he referring? A form of the phrase first appears in text with Aristotle's fourth century BC Historia Animalium. In a discussion about the strange hybrids that seem to found on the African continent, Aristotle writes, "'a certain proverb is current, that Libya always produces something new"' (quoted in Feinberg and Solodow 2002, 257). Occurring in a similar connotation, the phrase was textualized next by Pliny the Elder sometime early in the first century $\mathrm{AD}$ and then by Zenobius, a Greek philologist, in the second century, although Zenobius altered it to "Libya is 
always producing something evil" (Feinberg and Solodow 2002, 258). The convention appears over a thousand years later in western Europe with the writings of Erasmus, although he was likely the one to assign the phrase its more current form and connotation, changing "Libya" to "Africa," and using the term in a more charming context, one of admiration rather than revulsion or reservation (Feinberg and Solodow 2002, 259). With Erasmus's usage, the phrase propelled throughout Renaissance texts, being cited, for instance, by Rabelais, who wrote, "you know well that Africa always brings something new" (quoted in Feinberg and Solodow 2002, 260). By the time the phrase appears as the title of Blixen's memoir, it had changed meanings a number of times but always carried with it the burden of its textual heritage, a genetic paper trail leading back thousands of years. Initially a statement of bewilderment and curiosity, it came to be one of revulsion, then wonder and awe. It has changed from colloquialism to literary obscurity to academic convention. When archaeologists/ anthropologists, geneticists, or biologists use the phrase today, might they consider the palimpsest of meaning and context behind the words? This is but one example of how our words, no matter how benign they may seem, are often precariously laden with an intertextual past.

Let me give you another example of how the use of a name or phrase- whether flippant or flagrant — can be a ticket to a centuries old debate. In January of 1988, Newsweek published the cover story "The Search for Adam \& Eve: Scientists Explore a Controversial Theory About Man's Origins". The cover featured "sophisticated and attractive nude portraits of a black Adam and Eve sharing the apple, with the snake looking on approvingly" (Oppenheimer 2003, 45). In a single illustrated statement, science and religion, material fact and sacred mythology, can once again become entangled in an authoritative argument over humanity that has been going on since the time of Galileo, the Enlightenment, and even longer. Conduct a simple internet search for "mitochondrial Eve" and one is likely to be bombarded with a heated multivocality, finding a plethora of multimedia engaged in a discourse about the origins of humanity, with scholarly and journalistic articles, lay-person blogs, satirical cartoons, television documentaries, radio programs and podcasts, and any other form of human expression, all referencing each other to form a polemical web of ideas and discussion. Curiously, intertextually referencing Biblical terms seems to be a common temptation among social and physical scientists. We find Steven Oppenheimer's The Real Eve: Modern Man's Journey Out of Africa (2004) and Out of Eden: The Peopling of the World (2003), Robert Ardrey's African Genesis: A Personal Investigation Into the Animal Origins and Nature of Man (1977), or Richard Dawkins' River out of Eden: A Darwinian View of Life (1996), among others.

So, why is it necessary to discuss Biblical myth in a scientific book? Why use JudeoChristian terminology in what is supposed to be a scientific arena? Certainly, a scientific journal article that frames itself with a title playing with Biblical allegory engages in a precarious game of 'religion vs. science' where we are unsure if the two are combatants or teammates. As Wiktor Stoczkowski $(2002,5)$ points out, scientists of the 18th and 19th centuries "set out to conquer a prehistoric past that had been recently rediscovered. Having as their only enemy the errors of religious beliefs, all they had to do was to choose: either they could reject the biblical Genesis, which might ultimately be transformed into an allegory of obscure significance, or they could adopt a hostile stance towards the naturalist view, in defense of the Christian doctrine." So why do modern scientists engage in this old polemic? The answer is that, whether it is science or myth or religion, these disciplines are concerned with the same subject matter, and thus they form 
a single discourse, one ongoing discussion about who we are and where we came from. It is then impossible for any one text to escape the family tree of which it is a part and so intentional intertextuality and overt reference become necessary. Rather than pretending that Biblical myth and scientific theory are of different concerns, we must engage the other in a dialogue, or at least acknowledge its voice. Stoczkowski $(2002,197)$ explains that innovative theories of anthropogenesis are provided for by the "raw materials" of earlier conceptions and, at the same time, are influenced by the historical and cultural contexts which framed those earlier conceptions. In this way, "every new act is played here on a stage that is already constructed, prepared by the past. Continuity and discontinuity, innovation and tradition represent two sides of the same coin."

Intertextuality is not necessarily a choice but, rather, an inevitability. New things cannot be said without communicating with what has been said. As Culler (1976, 1382) explains:

...the notion of intertextuality names the paradox of linguistic and discursive systems: that utterances or texts are never moments of origin because they depend on the prior existence of codes and conventions, and it is the nature of codes to be always ready in existence, to have lost origins. It is difficult to explain what it is that enables is to make sense of a new instance of discourse, but whatever intelligibility a discursive sequence achieves depends on intertextual codes.... Intertextuality is less a name for a work's relation to particular prior texts than an assertion of a work's participation in a discursive space and its relation to the codes which are the potential formalizations of that space.

Culler $(1976,1393)$ goes on to say that intertextuality "leads one to think of a text as a dialogue with other texts, an act of absorption, parody, and criticism, rather than an autono- mous artifact which harmoniously reconciles the possible attitudes toward a given problem." Past and current theories form not a binary system but an analogue continuum of discourse, a space that one may enter with the mention of a single word. But this is not to be avoided or lamented. The intertextual space is one that often serves rather than hinders a discursive engagement. Stoczkowski (2002, 198) writes:

Contrary to what is often thought, scientists do not draw their conclusions from empirical data, any more than they rewrite history in terms of prevailing ideology. In fact, they rather try to organise the heterogeneous conceptual materials that society places at their disposal, and these include new facts and recent ideologies just as much as ancient commonplaces.... It is not a question of some liberation from the past, but rather of learning to make good use of it.

Because we cannot avoid them, we must keep in mind how our intertextual references form relationships between texts, ideas, people, and actions. We must "make good use" of our words. One way of doing so is to keep in mind the story we are telling when we write an academic text. What narrative arises from our data and interpretations? In a sense, we are telling the story of humanity, a performance which cannot be treated frivolously. These tellings belong to a genre of discourse-perhaps the oldest genre of discourse-about where we came from. Misia Landau (1991, x) has suggested that palaeoanthropological texts from the time of Charles Darwin "are determined as much by traditional narrative frameworks as by material evidence" and that these texts, considered as narratives, "approximate the structure of the hero tale," featuring "a humble hero who departs on a journey, receives essential equipment from a helper or donor figure, goes through tests and transformations, and finally arrives at a higher state." She goes on to point out that "this 
narrative schema can accommodate widely varying sequences of events, heroes and donors corresponding to the underlying evolutionary beliefs of their authors." When we write or read a journal article or a book, who are "the heroes" of the tale? What is their journey? Where is it taking them, from where are they departing, and why? Even if one rejects the idea that a scientific text can be thought of as a mythic narrative, one might not so easily be inclined to dismiss the idea that our words tell a story, no matter what that story might be. And so, what to do? Landau $(1991,175)$ offers this advice: "Given that evolutionary explanation is by definition a kind of narration, paleoanthropologists might consider wrestling with the 'story-telling dragon,' rather than avoiding it altogether. Some literary scholars would argue that there is no escape. It is storytelling that makes us human." But how will we, as Stoczkowski (2002) suggests, make good use of the current data, be it genetic or archaeological, and how will the stories we tell about our beginnings relate to the narratives we construct about our lives and the world we live in now?

\section{The Importance of Narrative:}

\section{LIVING STORIES}

In the collection Rethinking the Human Revolution, Sally McBrearty (2007) authors a chapter entitled "Down with the Revolution". McBrearty (2007, 145) explains that the conceptual term "Human Revolution" is a "serious misnomer," as it is based upon erroneous interpretations of Middle to Upper Palaeolithic data. Despite this, the idea of some kind of revolution has persisted, and scientists continue to seek one out. This idea is so compelling because it presents "a single extraordinary moment that defines what it is to be human and explains all or most of subsequent events in prehistory." McBrearty suggests that "this quest for this 'eureka moment' reveals a great deal about the needs, desires, and aspirations of archaeologists, but obscures rather than il- luminates events in the past" and "continues to put Europe on centre stage, casting it either as the arena where the actual events of human origins were enacted, or as the yardstick by which human accomplishments elsewhere must be measured." McBrearty's statements, though directed as critique, are apt, and apply not only to the archaeologists, but their audiences - indeed, to humanity as a whole. Everyone has needs, desires, and aspirations, and in many ways these are met through a process of reinterpreting the narratives that surround us, that inform our identities and experiences. As White (1980, 5) explains, "narrative might be considered a solution to a problem of general human concern, namely, the problem of how to translate knowing into telling, the problem of fashioning human experience into a form assimilable to structures of meaning that are generally human rather than culture-specific." This is perhaps one of the performative functions of intertextuality, where a text builds on others that describe what a culture did in order to articulate what a culture is capable of (Culler 1976, 1383). The narratives we tell, and the way we incorporate other narratives into our own, are integral to our sense of who we are and what we are about. Johnson $(1993,150)$ writes, "the self is defined by not only its biological makeup as a physical organism, but also by its ends, its interpersonal relationships, its cultural traditions, its institutional commitments, and its historical context. Within this evolving context it must work out its identity." Narratives of human evolution are discourses of identity. We are all authors of those narratives, always asking, "Of what story or stories do we find ourselves a part?" and, in response, "What are we to do?" This is why the intertextual process must be carried out with a purposeful consideration. Braid $(1996,6)$ tells us,

Because of parallels between lived experience and the process of following a narrative, the listener's struggle to follow 
a narrative must be seen to be an experience in its own right. Part of this experience of following involves a recontextualization of the narrative imagery and events in terms of the listener's own life experience. In this sense personal narratives can generate experiential resources for the listener - resources that may be "thought with" and "thought through" in the struggle to make sense of the world.

In this way, life is a narrative, and what informs and frames that narrative are the foundational aspects of place, belief, and action. Just as story can inform identity, both can inform action. Economic and political policies can be built on the interpretations of scholars, as can social and cultural understandings and opinions. Our beginnings will likely influence our ends and the interpretation of the means to those ends. Zerubavel (2003, 101) explains,

the special mnemonic status of beginnings is quite evident from the disproportionately high representation, in our general memories from college, of the first few weeks or our freshman year. It also explains the significant role of 'origin myths' in defining social communities as well as in solidifying the legitimacy of political regimes. Origins help articulate identities, and where communities locate their beginnings tell us quite a lot about how they perceive themselves.

We might think of origin myths not as archaic artifacts but as ongoing processes of identity-establishment. Those origin myths, those stories we tell ourselves about our beginnings, are unavoidably interconnected with scientific interpretation and vice versa. Landau (1991, 183) writes, "In the final analysis, the truly significant test of scientific theories of human evolution may lie in their workability in everyday practice." How we live those scientific theories and narratives about the human species may ultimately prove their relevance to the human species.

\section{DraWing Lines by SAying Words: The Intertextual Construction of Dichotomies}

My fate is to live amid varied and confusing storms. But for you, perhaps, if as I hope and wish you will live after me, there will follow a better age. This sleep of forgetfulness will not last for ever. When the darkness has been dispersed, our descendants can come again in the former pure radiance [Petrarch. Africa, IX, 451-57].

The language used in the discourse surrounding the origins of humanity, whether implicit or explicit, cannot avoid the reification of certain concepts or conventions. Within narratives of human evolution we find the formation and solidification of particular binaries, dualities, or dichotomies. Historically, perhaps the most important or persistent are that of Self and Other, Human and Non-Human, or Human and Animal. In contemporary scientific narratives, the study of human development hinges primarily on two more recently established dichotomies: Modern and Non-Modern and African and NonAfrican. Again, though, these dichotomies, I will argue, are essentially part of the same intertextual discourse as that of Self and Other. As I will discuss further, the intertextual association of the dichotomies with one another, thus forming the conceptual timeplaces of Non-modern Africa and Modern NonAfrica, may have certain ramifications and so must be disseminated with some amount of self-reflexive caution.

\section{Modern and Non-Modern}

The idea of modernity is central to current discussions of human evolution. Anatomical modernity and behavioral modernity are the two main signifiers of our understanding of who we are and what distinguishes us from earlier members of our genus. And in conceiving of ourselves as modern, there exists the obvious opposition to something non-modern-that state of humanity prior 
to the advent of modernity, before we were truly us. But where does the concept of modernity come from?

Matei Calinescu $(1987,13)$ explains that the idea of modernity first appeared in the Middle Ages, when the adjective and noun modernus was coined from the adverb modo, which meant "recently, just now." The major antonym of modernus was antiquus, meaning 'ancient, old.' By the tenth century, the words modernitas and moderni became popular, meaning 'modern times' and 'men of today,' respectively. Calinescu (1987, 14) suggests that "the distinction between antiquus and modernus seems to have always implied a polemic significance, or a principle of conflict." Previously, the classical Latin language had no opposition between modern and ancient because the "classical Latin mind" had no interest in "diachronical relationships" (Calinescu 1987, 14). And it wasn't until the Renaissance that the dichotomy became acute within sociocultural awareness. This was in part due to the invention of the mechanical clock in the late thirteenth century, along with the development of a concept of "practical time" in regards to "action, creation, discovery, and transformation," as opposed to the medieval sense of theological time, which was vast, immeasurable, and entirely abstract (Calinescu 1987, 19-20).

Calinescu $(1987,42)$ goes on to say:

[The] bourgeois idea of modernity...has by and large continued the outstanding traditions of earlier periods in the history of the modern idea. The doctrine of progress, the confidence in the beneficial possibilities of science and technology, the concern with time (a measurable time, a time that can be bought and sold and therefore has, like any other commodity, a calculable equivalent in money), the cult of reason, and the ideal of freedom defined within the framework of an abstract humanism, but also the orientation toward pragmatism and the cult of action and success-all have been associated in various degrees with the battle for the modern and were kept alive and promoted as key values in the triumphant civilization established by the middle class.

With the inception of practical time came the practicalities of time; past, present, and future became conceptually graspable and even observable. In a sense, the idea of progress became not only pragmatic, but essentially so. The current state of things became a litmus test of progress and human development; only if we had noticeably moved away from what we were could we have any confidence that we could become what we wanted to be. As Svetlana Boym $(2001,22)$ explains, "Modernity and modernisms are responses to the condition of modernization and the consequences of progress." The future was seen as a time of reason, of self-control, of refined humanity, and this future was conceptualized both temporally and geographically as a Utopia; a time-place that represented the ends of modernity and progress:

Indeed the rage for utopia-either directly and positively or by way of reaction and polemicism-pervades the whole intellectual spectrum of modernity from political philosophy to poetry and the arts.... Utopian imagination as it has developed since the eighteenth century is one more proof of the modern devaluation of the past and the growing importance of the future. Utopianism, however, would hardly be conceivable outside the specific time consciousness of the West, as it was shaped by Christianity and subsequently by reason's ap-

\footnotetext{
${ }^{1}$ It is interesting to note that the diachronic view of time facilitated not only the conception of modern and non-modern and of progress but also the very idea of 'revolution.' Revolution, however, linguistically and conceptually denotes something that scholars who promote the Human or Cultural Revolution theory like Richard Klein, a major proponent of the Human Revolution model, would likely reject: a cyclical model of time alternating between utopias and dystopias, with revolution implying a "return to a purer initial state" (Calinescu 1987, 22).
} 
propriation of the concept of irreversible time [Calinescu 1987, 63, my italics]. ${ }^{1}$

The movement toward reason, seen as a forward movement through time, established a "devaluation of the past" - the "past" being a time when a lack of reason seemed to rule our species. Modernity became what we strived for, and pre-modernity-or non-modernity - was what we moved away from in our natural progression through time toward reason and refinement.

\section{Africa and Non-Africa}

Over the past couple of decades, Africa has been situated within the scientific mind as the place of origin for the Homo genus and the modern human species. But Africa has become much more than a geographic region. By "Africa," we refer not only to geography but to genetics, which become anchored to one another by association, like Adam who was made of the dust of the Garden, or the peasant whose soil is in his veins. Africa has, in a sense, likewise become more than geography or genetics. It has become a mindscape - a conceptual domain that involves ideas about human identity, capacity, and potential. But a clear definition of just what "Africa" is lacks explicitness. It is something that people who participate in the discourse must discern based on the usage of the term-on its textual context-and how "Africa" passes from one text to another, from one theory to another. In any event, what has become clear is that the world has begun to be conceived of as consisting of two parts: Africa and Non-Africa, the place we came from and the place we went to. Referring to the Out-of-Africa replacement model, the multiregional model, and the trellis model of recurrent genetic interchange, Lansana Keita $(2004,1)$ writes, "despite important differences the three major theories of human anthropological evolution all subscribe in greater or lesser degrees to what one might call 'the Africa-Rest-of-the-World' evolutionary hypothesis, although there is no supportable epistemological and scientific basis for making this dual distinction." Keita $(2004,5)$ goes on to say, "The conclusion one is led to after an epistemological analysis of the extant evolutionary models and theories is that ideological considerations are at work here. The implicit goal on grounds of a naïve hierarchical racialism is to make of Africa's population a special case in the world's genome bank." While I wouldn't necessarily accuse any researchers of an "implicit goal on grounds of a naïve hierarchical racialism," I would venture to point out that the AfricaRest-of-the-World (or Africa and Non-Africa) duality does persist in the discourse regarding current genetic research. McBrearty and Brooks (2000, 453) might agree. They write:

Because the earliest modern human fossils, Homo sapiens sensu stricto, are found in Africa and the adjacent region of the Levant at $>100 \mathrm{ka}$, the "human revolution" model creates a time lag between the appearance of anatomical modernity and perceived behavioral modernity, and creates the impression that the earliest modern Africans were behaviorally primitive. This view of events stems from a profound Eurocentric bias and a failure to appreciate the depth and breadth of the African archaeological record.

A quick review of some current literature will help to illustrate the Africa and NonAfrica linguistic binary. For instance, the article "An X-Linked Haplotype of Neandertal Origin Is Present Among All Non-African Populations" by Yotova et al. (2011) makes a distinction between, as the title suggests, African and non-African populations. The authors discuss evidence that "Neandertals contributed to the genetic makeup of modern human populations outside Africa," which may have facilitated "adaptations to novel environmental conditions that actually contributed to the successful expansion of human migrants from Africa to other continents" (Yotova et al. 2011, 1961). 
What the authors are suggesting is a type of "hybrid vigor" among all non-African populations. This theory is significant because, not only does it posit a genetic difference among African and non-African populations, it proposes the idea that nonAfrican populations may be better suited to non-African environments on the genetic, rather than the phenotypic, level. This is worrisome, especially when one considers the fact that many people of recent African ancestry do indeed reside in non-African parts of the world. Would we say, then, that they are "less suited"? Likely not, but perhaps the danger lies not in explicitness but in those naive interpretations based on perceived implications.

The article "African Origin of Modern Humans in East Asia: A Tale of 12,000 Y Chromosomes" by Ke et al. (2001) provides a diagram of $\mathrm{Y}$ chromosome haplotypes throughout the world's populations. The diagram distinguishes African-specific haplotypes, non-African-specific haplotypes, and shared between Africans and non-Africans. The phrase "African and other world populations" is also used (Ke et al. 2001, 1152).

But can we make such definitions? Is there a real spot where Africa ends and NonAfrica begins? Just where is the defining line, not only now, but when our ancestors supposedly left Africa? Where can we place that point of exit? As Pam Willoughby $(2007,94)$ explains, "The first modern humans outside of Africa are those found at Mugharet es Skhül and Jebel Qafzeh, and they date to MIS stage 5e (Bar Yosef 1989a, 1989b; Tchernov 1988). Whether or not this represents the start of the Out of Africa II migration can be disputed, since all proxy indicators show that at this time the Levant was biogeographically part of Africa." If we begin to think of the world as biogeographically analogue, rather than binary, how might things differ with a world conceptualized as being composed of Africa and Non-Africa? Keita $(2004,2)$ reminds us that not only should it "be obvi- ous that members of hominid groups that migrated during the Paleolithic era had absolutely no idea whether they were migrating to other parts of Africa or leaving the continent altogether," but that migrations were occurring within Africa as well. The world, then, is more accurately conceived of as "ecological and environmental zones" defined by "measurable differences in climate and ecology" than continents or geo-political landmasses defined only by imposed conceptual borders.

If the binary continues to persist in scientific discourse — with a likely influence on political and sociocultural discourses-perhaps of most concern is how Africa has been and will be portrayed: as Homeland, Crucible, or Cage. In some cases, Africa has been portrayed as that place we left to become modern-to become fully human-and it wasn't until we left Africa that we could become who we are. The Human Revolution model, for instance, suggests this view, as does the Hybrid Vigor hypothesis. In other texts, Africa has been portrayed as a crucible-that chamber in which various forces came together to create us as we are, or us as we needed to be in order to become who we are. Still in others, Africa is portrayed as homeland-that ancestral place to which we might always look with affection and awe. Svante Pääbo, in a TED Talk in July 2011 in Edinburgh, Scotland, said, "What I often like to say is that from a genomic perspective, then, we are all Africans. We either live inside Africa today or in quite recent exile." Within the language of Pääbo's narrative, although we are all Africans, there still exists a dichotomy between Africa and the rest of the planet. He says, "You find a certain amount of genetic variation in Africa, and if you look outside Africa, you actually find less genetic variation." Pääbo's presentation is politically liberal and yet the African/Non-African divide is propagated. The reason I reference Pääbo's TED Talk rather than one of his articles is because of his audience. TED Talks are watched by hundreds of thousands of 
people across all demographics. The broadcasting of these binaries, as well as ideas depicting Africa as homeland, crucible, or cage, are likely to reach a wide audience through various multimedia. How will they synthesize these terminologies and ideas into their personal narratives? What ideas will they incorporate into their lived identities? While the language used by these researchers does not intentionally create divisions, it does construct conceptual dichotomies. While seemingly benign, the conceptualization of the world as African and Non-African or Africa and Non-Africa is a potentially worrisome categorization.

\section{Time-Space and Time-Places: The Where and When of Self and Other}

One concept important in the theoretical developments of humankind since the nineteenth century is that of time-space associations. Fabian $(2002,12)$ writes, "relationships between parts of the world (in the widest sense of both natural and sociocultural entities) can be understood as temporal relations. Dispersal in space reflects directly, which is not to say simply or in obvious ways, sequence in Time." This time-space association is also important to discourses in human development. In 1800, Joseph-Marie Degérando wrote in his Considerations on the Various Methods to Follow in the the Observation of Savage Peoples, "The philosophical traveler, sailing to the ends of the earth, is in fact travelling in time; he is exploring the past; every step he makes is the passage of an age" (quoted in Robben and Sluka 2007, 34). To those early explorers and observers of unfamiliar human societies, whether they were naturalists or colonialists, distant lands were conceived of as distant times. One might argue that this perception continues in discourse regarding humanity's African origins. Whether we say, "Once we left Africa we became modern" or "Once we became modern we left Africa," we are agreeing on two dichotomies: NonModern and Modern and Africa and NonAfrica. These two temporal and geographic dichotomies become intertextually associated and integrated as a single dichotomy of time-spaces or time-places: Non-Modern Africa and Modern Non-Africa. Politically and socially, caution is necessary:

The genetic evidence that modern humans emerged from Africa, leaving behind them 'homeland' representatives whose descendants still live in Africa and are self-evidently 'fully modern' in every way, has disturbing implications for continuing Western perceptions of modern Africans. Although the danger of these views is obvious, the mindset of some European archaeologists has remained unchanged [Oppenheimer 2003: 89-90].

What we are talking about here is the distinction between Self and Other and what kind of policies, actions, or ideas such a distinction can motivate or allow within the sociopolitical sphere. As Fabian $(2002,1)$ reminds us, "there is no knowledge of the Other which is not also a temporal, historical, a political act." When we begin to conceive of groups of people as Other, a dangerous liberty begins to grow, often materializing in a license for discrimination. But how do we make these distinctions? Where do we draw the lines between Self and Other, temporally, spatially, or politically? This line was first drawn, perhaps, between Human and Animal; Civilization and Wild; Man and Beast. Wiktor Stoczkowsi (2002, 42-43) writes:

The idea of the animal-we should rather say bestial - condition of our ancestors is part of the classic legacy of conjectural anthropology.... The tendency to compare the earliest humans with animals has existed from Antiquity, and it is easy, starting from a few texts chosen at random, to draw up a list of the main attributes ascribed by conjectural history to that 'bestial' state: absence of religion, absence of government, absence of laws, absence of language, absence of individual property, absence of clothing. 
Here we have a definition by negatives, in which every item expresses the nonexistence of 'typical' manifestations of culture. So the bearers of those attributes find themselves again confined to the state of nature, represented in the image of animals and, like them, lacking everything believed to be specific to humans. Such a view of animality comes from a simple inversion of the image we have of humans, that is, of ourselves.

Since Antiquity, there has been a perceived point at which we ceased to be the Other and became Us (Stoczkowski 2002, 60). Whether this point refers to the transition of the Ancients into the Moderns, animals into humans, natural man into social man, or the savage into the civilized, a dichotomy between Self and Other seems to have long preoccupied scholars of religion, philosophy, and science-indeed, scholars of the human condition. It is not surprising, then, that in the recent scientific explorations of human evolution, the dichotomy of Self and Other has also been on the forefront. How else are we to know who we are than knowing who we are not? The Non-Modern Africa and Modern Non-Africa time-place dichotomy is, essentially, a reworking of the Self and Other or Human and Non-Human binaries. We know that we are Modern, so the Other is Non-Modern. And, if we know that we reached modernity outside of Africa, then Africa is the place of the Other, or at least the place where the Other became the Self. As Willoughby $(2007,5)$ explains:

Over the last two to three decades, archaeologists and palaeoanthropologists have written about early modern Africans in the same way that Europeans initially wrote about non-Western people. Both are treated as distinct, as 'others,' outside the range of what it means to be cultured or civilized. Early European explorers were fascinated by the cultural and biological diversity of people they encountered worldwide. But there was little attempt to link non-Western history and culture with Western technology and achievements. Just as indigenous groups became people without history (Wolf 1982, 1997), early modern Africans and their Neanderthal cousins in Eurasia have become people without behavior or true culture (Willoughby 2000; Speth 2004).

In conceiving of the Other, we must place the Other somewhere in time, somewhere in history, somewhere in space, and somewhere in place. We are left, then, with an intertextual conception that looks like this: Non-Modern Africa as Other and Modern Non-Africa as Self.

Our new scientific definitions are meant to inform the age-old question vital to selfconceived identity. But, at their core, have our new definitions of humanity differed much from our old definitions? In a meta-study of 24 texts examining the question of human origins published between 1820 and 1986 , Wiktor Stoczkowski (1994, 38-39) writes,

How did humans appear? It would be difficult to understand the methods and structures of the scenarios that attempt to answer this question without first explaining what their authors understand by 'humans'. 'Humans' are defined by a conglomeration of characteristics that are given the status of distinguishing features of our biological family. Consequently, to explain anthropogenesis means to explain the origins of these human characteristics.... If we standardize the terminology which designates 'human' characteristics in our twenty-four texts, their profusion can be reduced to a list of thirty-eight properties.... It is striking that the core of this list, consisting of the most frequently mentioned characteristics, has changed very little over 150 years. The leading roles are constantly played by attributes such as tools, bipedalism, free hands, language, social life and cooperation.

If, as Stoczkowski suggests, very little has 
changed in our definitions of the Self and Other-or the Human and Non-humanover the last 150 years, what might we predict of the next 150 years?

\section{And Away We Go...}

How will these time-place dichotomies continue to shape our understanding of human evolution - of our story - and vice versa? We have already seen in the last couple of decades how the discourse has been unfolding, but how will it continue to influence our daily world, our lived experience? Will the Africa and Non-Africa dichotomy enter political or economic discourse? Many may argue that it already has-that the idea of Africaand-the-Rest-of-the-World has been present in the Western mind since the time of Aristotle. In the years to come, how will we identify the Other, and where will we place the Other in space and time? What places have we left, and where are we going? And, most importantly, who are 'We'? As Landau (1991, 178) reminds us, "the fossil record may appear to support the notion that we are truly heroes to have survived. Or it can tell a different story: we are merely the remnants of a golden age." In the end, it will be up to us to decide who we are, where we came from, and where we are going; not necessarily by the data we discover, but by the way we tell our story.

\section{REFERENCES}

Abi-Rached, Laurent, Matthew J. Jobin, Subhash Kulkarni, Alasdair McWhinnie, Klara Dalva, Loren Gragert, Farbod Babrzadeh, Baback Gharizadeh, Ma Luo, Francis A. Plummer, Joshua Kimani, Mary Carrington, Derek Middleton, Raja Rajalingam, Meral Beksac, Steven G. E. Marsh, Martin Maiers, Lisbeth A. Guethlein, Sofia Tavoularis, Ann-Margaret Little, Richard. E. Green, Paul J. Norman, Peter Parham. 2011. "Shaping of Modern Human Immune Systems by Multiregional Admixture with Archaic Humans." Science 334:89-94.

Ardrey, Robert. 1977. African Genesis: A Per- sonal Investigation into the Animal Origins and Nature of Man. Bantam Books.

Boym, Svetlana. 2001. The Future of Nostalgia. New York: Basic Books.

BRaid, Donald. 1996. "Personal Narrative and Experiential Meaning." The Journal of American Folklore 109(431):5-30.

Brigg, Charles L. 1996. "The Politics of Discursive Authority in Research on the Invention of Tradition." Cultural Anthropology 11(4):435-469.

Briggs, Charles L., and Richard Bauman. 1992. "Genre, Intertextuality, and Social Power." Journal of Linguistic Anthropology 2(2):131-172.

Brown, P., T. Sutikna, M. J. Morwood, R. P. Soejono, Jatmiko, E. Wayhu Saptomo, And Rokus Awe Due. 2004. "A New Small-Bodied Hominin from the Late Pleistocene of Flores, Indonesia." Nature 431:1055-1061.

Calinescu, Matei. 1987. Five Faces of Modernity: Modernism, Avant-Garde, Decadence, Kitsch, Postmodernism. Durham: Duke University Press.

Culler, Jonathan. 1976. "Presupposition and Intertextuality." MLN 91(6):13801396.

Dawkins, Richard. 1996. River out of Eden: A Darwinian View of Life. Basic Books.

Degérando, Joseph-Marie. 2007. “The Observation of Savage Peoples." In Ethnographic Fieldwork: An Anthropological Reader, edited by Antonius C.G.M. Robben and Jeffrey A. Sluka, pp. 33-39. Malden, MA: Blackwell Publishing.

Fabian, Johannes. 2002. Time and the Other: How Anthropology Makes its Object. New York: Columbia University Press.

Feinberg, Harvey M., and Joseph B. Solodow. 2002. "Out of Africa." The Journal of African History 43(2):255-261.

Forth, Gregory. 2005. "Hominids, Hairy Humanoids and Science of Humanity." Anthropology Today 21(3):13-17.

Goebel, Ted, Michael R. Waters and DenNIS H. O'Rourke. 2008. “The Late Pleis- 
tocene Dispersal of Modern Humans in the Americas." Science 319:1497-1502.

Johnson, MARK. 1993. Moral Imagination: Implications of Cognitive Science for Ethics. Chicago: University of Chicago Press.

Ke, Y., B. Su, X. Song, D. Lu, L. Chen, H. Li, C. Qi, S. Marzuki, R. Deka, P. Underhill, C. Xiao, M. Shriver, J. Lell, D. Wallace, R.S. Wells, M. Seielstad, P. Oefner, D. Zhu, J. Jin, W. Huang, R. Chakraborty, Z. Chen, and L. Jin. 2001. "African Origin of Modern Humans in East Asia: A Tale of 12,000 Y Chromosomes." Science 292:1151-1153.

Keita, Lansana. 2004. "The 'Africa and the Rest of the World Evolutionary Hypotheses': An Exercise in Scientific Epistemology." The African Archaeological Review 21(1):1-6.

Landau, Misia. 1991. Narratives of Human Evolution. New Haven: Yale University Press.

McBrearty, Sally. 2007. "Down with the Revolution." In Rethinking the Human Revolution, edited by Paul Mellars, Katie Boyle, Ofer Bar-Yosef \& Chris Stringer, pp. 133151. Cambridge: McDonald Institute for Archaeological Research at the University of Cambridge.

McBrearty, Sally and Alison S. Brooks. 2000. "The Revolution that Wasn't: A New Interpretation of the Origin of Modern Human Behavior." The Journal of Human Evolution 39:453-563.

Tierney, John. 11 January 1988. "The Search for Adam and Eve." Newsweek 111:46-52.

Oppenheimer, Stephen. 2003. Out of Eden: The Peopling of the World. London: Constable and Robinson Ltd.

- 2004. The Real Eve: Modern Man's Journey Out of Africa. New York: Carol and Graf Publishers.

PÄ̈̈B, Santo. July 2011. "DNA Clues to Our Inner Neanderthal.” TED Talk. Edinburgh, Scotland. http://www.ted.com/ talks/lang/en/svante_paeaebo_dna_ clues_to_our_inner_neanderthal.html.
STOCZKOwsKi, WikTOR. 2002. Explaining Human Origins: Myth, Imagination and Conjecture. Translated by Mary Turton. Cambridge: Cambridge University Press.

White, Hayden. 1980. "The Value of Narrativity in the Representation of Reality." Critical Inquiry 7:5-27.

Willoughby, Pamela R. 2007. The Evolution of Modern Humans in Africa: A Comprehensive Guide. Lanham, Maryland: AltaMira Press. Yotova, Vania, Jean-Francois Lefebvre, Claudia Moreau, Elias Gbeha, Kristine HovHANNESyan, Stephane Bourgeois, Sandra Bédarida, Luisa Azevedo, Antonio Amorim, Tamara Sarkisian, Patrice Hodonou Avogbe, Nicodeme Chabi, Mamoudou Hama Dicko, Emile Sabiba Kou' Santa Amouzou, Ambaliou Sanni, June Roberts-Thomson, Barry BoetTCher, Rodney J. Scott, and Damian Labuda. 2011. "An X-Linked Haplotype of Neandertal Origin Is Present Among All NonAfrican Populations." Molecular Biology and Evolution 28(7):1957-1962.

Zerubavel, Eviatar. 2003. Time Maps: Collective Memory and the Social Shape of the Past. Chicago: University of Chicago Press. 